\title{
A shared water risk assessment for a vulnerable river basin: River Rwizi in Uganda
}

\author{
P. Songa ${ }^{1}$, J. Rumohr ${ }^{2} \&$ R. Musota ${ }^{3}$ \\ ${ }^{1}$ Ove Arup \& Partners Ltd, Leeds, UK \\ ${ }^{2}$ GIZ, Uganda \\ ${ }^{3}$ Directorate of Water Resources Management, \\ Ministry of Water and Environment, Uganda
}

\begin{abstract}
Covering approximately $8,000 \mathrm{~km}^{2}$, the River Rwizi catchment stretches across 10 districts in south-western Uganda. Common economic activities carried out include agriculture, fish farming, tourism and local industry. Water users include industries and a municipality. In recent years, the catchment has featured prominently in national news due to frequent water resource problems, especially during the dry season. A water risk and sustainability study was carried out to support water stewardship initiatives and the development of a catchment management plan. The study examined the hydrology and water use patterns in the catchment. Uneven rainfall distribution (both in time and space), topography and wetlands drive the catchment's hydrology. However, existing river flow data cannot be relied upon, due to existing hydraulic characteristics at gauging locations as well as inconsistency in the record lengths. Groundwater quantity and quality are highly variable, and generally poor due to the geology of the area. Meanwhile, projections for domestic, agricultural and industrial water demand to 2035 indicate a steady increase, largely as a result of population growth and urbanisation. Pollution loads are also projected to increase. The study identified and ranked the key water-related risks to users in the catchment, including the causal factors. Possible mitigation measures were examined and a programme of long and short-term actions identified.

Keywords: water risk, water scarcity, water stewardship, catchment, shared risk, water demand, water resources.
\end{abstract}




\section{Introduction}

The Uganda Ministry of Water and Environment (MWE), through the Directorate of Water Resource Management (DWRM), partnered with GIZ, The Coca-Cola Africa Foundation and Century Bottling Company in Uganda on a joint project called "Improved Community Livelihoods and Sustainable Water Management in River Rwizi Catchment". The project aims to support efforts to increase water availability in the River Rwizi by developing sustainable water resources management and water use practices in the catchment. A water risk assessment study was carried out under this project to support the development of a water stewardship initiative in the catchment, as a means of addressing shared water risk.

\subsection{Scope and objectives of the risk assessment}

This was the first water risk assessment ever carried out for a river catchment in Uganda. Therefore, the scope of the project was wide, and included technical and socio-economic aspects of water resources and water use in the catchment. The overall objective of the project was to perform an assessment of the risk faced by the stakeholders due to the current state of water resources in the catchment. The project intended to provide an overview of the status of the catchment while identifying opportunities to manage it in a sustainable manner.

The main objective was underpinned by four specific objectives:

- To provide the scientific and economic basis upon which the Catchment Management Plan (CMP) could be developed.

- To create a highly participatory process to engage multiple stakeholders in a dialogue on shared water risks.

- To help to build a common understanding of the likelihoods, severities, causes and impacts of existing and future water-related risks.

- To identify and assess short and longer term actions that a multi-stakeholder partnership could undertake in order to reduce shared water risk.

\subsection{Study approach}

Given the wide scope of the project, the following approach was adopted for the study:

- $\quad$ Literature review: The River Rwizi catchment is a much-studied catchment locally, and therefore a significant number of reports and papers on technical and socio-economic issues were available in the public domain. Additional information was provided by the project stakeholders.

- Water resources assessment: Data on the catchment hydrology, hydrogeology and climate was obtained and analysed, and a natural water balance attempted. Water demand and water use information as also obtained and analysed. Potential changes in the quantity and quality of both surface and groundwater resources in the catchment were identified. 
- Environmental assessment: Information on the environment and ecology of the catchment was obtained, and assessment of environmental water needs was attempted.

- Institutional assessment: An overview assessment was made of the legal and policy framework within which water resources in Uganda are managed and regulated. The context of the newly-established catchment-based structure currently being implemented by MWE was examined.

- Stakeholder consultation: Following on from the literature review, waterrelated risks faced by water users in the catchment were identified through interviews with key informants in Mbarara municipality and through questionnaires administered to the Catchment Management Committee (CMC). Two consultative workshops with the Committee were held.

- Identification of mitigation options: A broad set of options was identified for mitigation of water risk. The options should be considered further, developed and refined when the management plan is being developed. The options outlined are a combination of hard measures such as new infrastructure, as well as softer approaches including new land and water management approaches.

- Economic assessment: A high-level cost-benefit assessment was carried out, which was used to inform the assessment of strategic interventions required.

- Recommendations: A series of recommendations was made which were specific to the catchment and the local water-sector. Opportunities for collaboration were identified within the sector and with on-going programmes.

\section{River Rwizi catchment}

River Rwizi is approximately $55 \mathrm{~km}$ long, and flows eastwards from the hilly south-western area of Uganda, eventually draining into Lake Victoria. There are several lakes in the lower reaches of the catchment, namely Lake Mburo, Lake Nakivale, Lake Kachera and Lake Kijanebalola. The altitude varies from 1,300 to 2,170 metres above sea level.

The river catchment covers an area of about $8,000 \mathrm{~km}^{2}$, and stretches across 10 districts in south-western Uganda. The upper, central and lower reaches of the catchment are covered by wetlands which make up about $3.5 \%$ of the total land area. Forests make up approximately $2.5 \%$ and open water $1 \%$, the rest consisting of open vegetation, grassland and shrubs [1]. The wetlands in the catchment play an important role in capturing and storing water, releasing it into the river channel over time. They attenuate high flows and also help in trapping and settling sediment.

\subsection{Catchment characteristics}

There are two parts to the Rwizi catchment which are hydrologically different. The upper catchment consists of the River Rwizi itself, traversing the districts of Buhweju, Sheema, Bushenyi, Mbarara, Ntungamo, Isingiro and Kiruhura before 
discharging into Lake Mburo. This part of the catchment covers an area of between 2,500 and $3,000 \mathrm{~km}^{2}$, and is the area that most previously-completed studies of the Rwizi catchment focus on. However, Lake Mburo is linked to Lake Nakivale through a series of wetland systems. Both lake systems are subsequently drained by River Kibale which flows through another series of wetlands into Lake Kijanebalola in Rakai district, draining Lake Kachera en route. From Lake Kijanebalola, the river changes name to River Bukora which flows finally into Lake Victoria. The full extent of the Rwizi catchment, therefore, combines these two 'sub-catchments'.

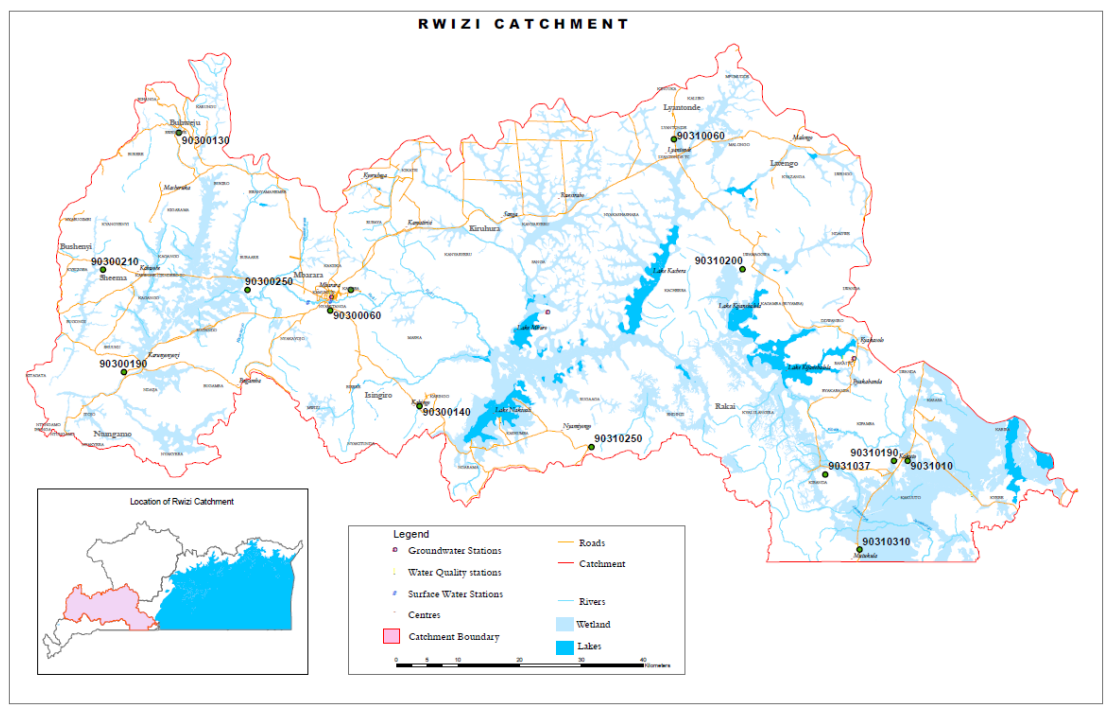

Figure 1: River Rwizi catchment.

\subsection{Economic importance}

The main economic activities in the catchment are subsistence and commercial crop agriculture, livestock rearing, fish farming, tourism through Lake Mburo National Park. Local industry is also common, especially brick making, sand mining, motor vehicle washing, motor vehicle repair garages, use of reeds for making baskets, mats and art pieces and wide-spread growing of eucalyptus trees). A diverse range of small, medium and large water users rely on the catchment's water resources for their supply, which include groundwater and surface water (from the river, lakes, naturally-occurring wetlands and constructed valley dams and tanks).

\subsection{National and international significance}

Over the past ten years, the River Rwizi has consistently featured in the national news on a near-annual basis, due to the frequent occurrence of water resource 
issues particularly during the mid-year dry season from June to October. The problems faced are known to be the result of a combination of factors, including climatic factors such as drought and low rainfall, abstraction pressures, current catchment management practices, inadequate infrastructure and infrastructure failure. The water resource problems faced in the Rwizi catchment are recognised both nationally and internationally [2].

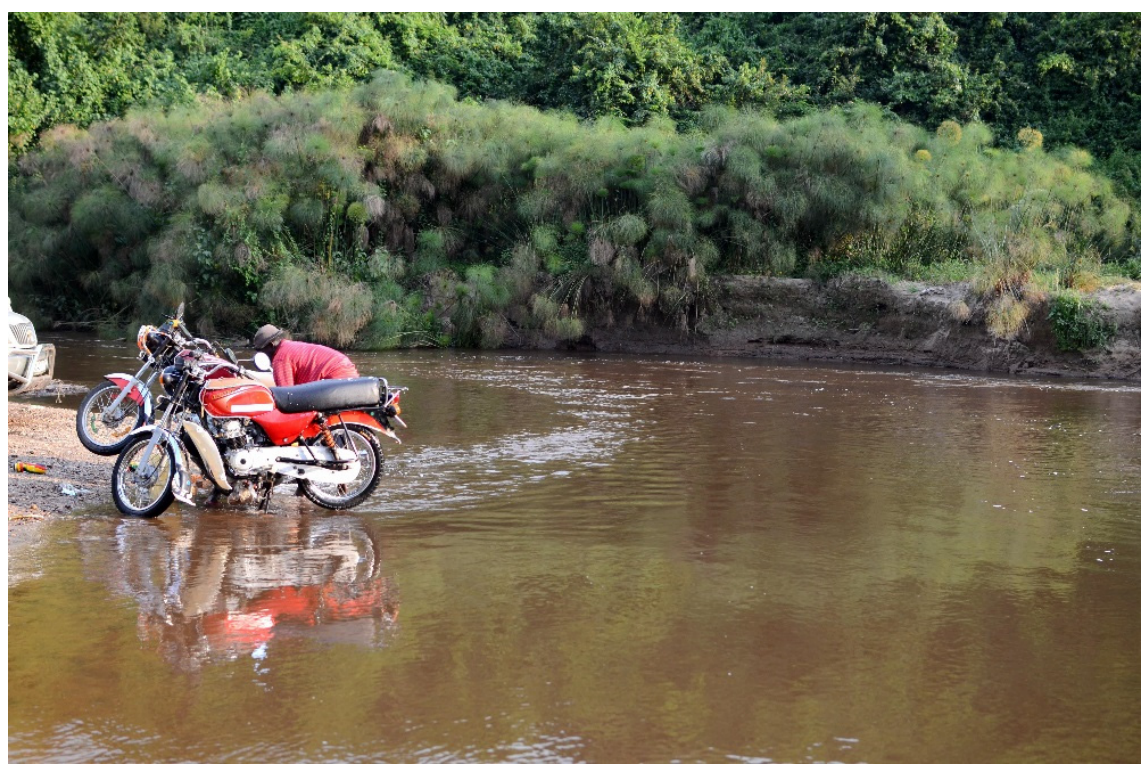

Figure 2: Washing motorcycles in the river.

\section{Summary of main findings}

The main findings of the study are summarised in the following paragraphs.

\subsection{Catchment climate, hydrology and hydrogeology}

Rainfall distribution - both in time and space - is a key influence on the catchment's hydrology. The average annual rainfall the catchment receives ranges from 690 to $1,300 \mathrm{~mm}$ (average $987 \mathrm{~mm}$ ). Rainfall distribution across the catchment is itself influenced mainly by the topography i.e. the presence of hills in the west and flat areas of wetland and open water in the east. The catchment experiences two rainy seasons (March to May, September to November) and two dry seasons (December to February, June to August). November and April are the wettest months, while July is the driest month, receiving $35 \mathrm{~mm}$ of rainfall on average. This is approximately $100 \mathrm{~mm}$ less than is received in the wettest months.

Analysis using the current river flow record indicated that the record is not reliable. This is mainly due to the stage-discharge relationships at the gauging locations in Mbarara town and upstream being unreliable and changing over time. 
In addition, some of the gauging locations are not suitable for flow measurement due to structures such as weirs causing hydraulic effects (Figure 3), rendering it difficult to establish the true relationship between flow and water level. An earlier water resources study [3] came to similar conclusions about the flow data. As a result, the natural water balance could not be accurately assessed.

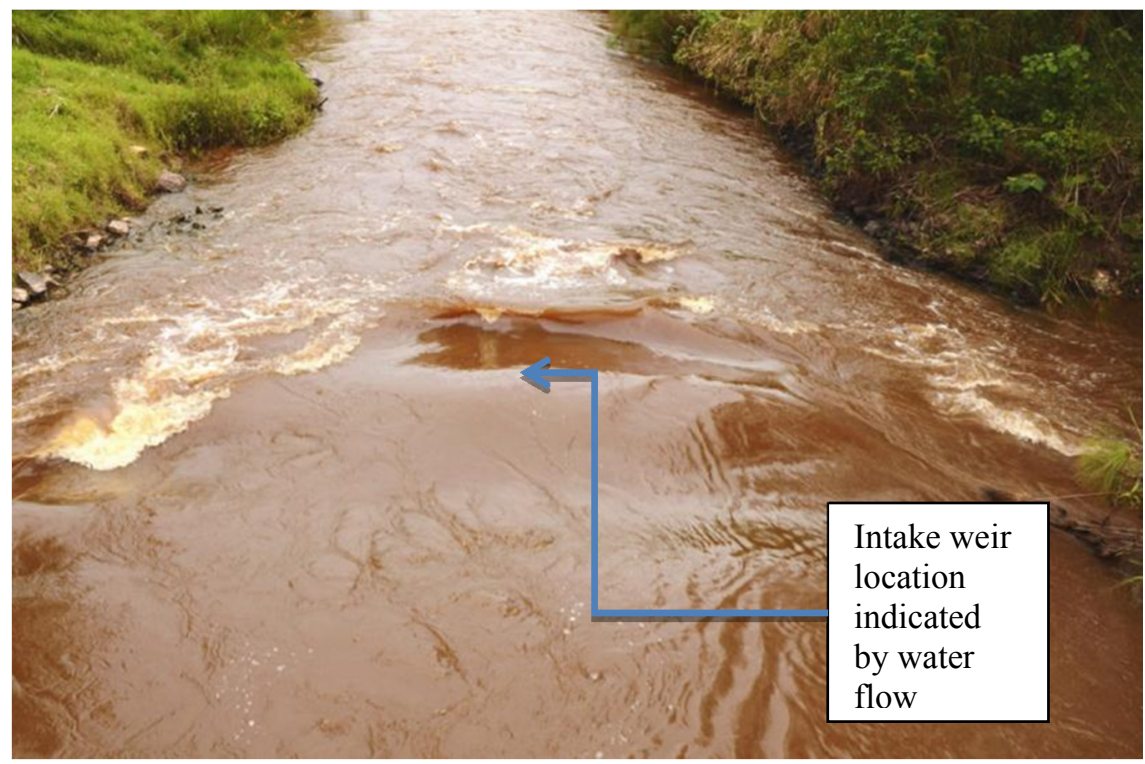

Figure 3: Gauging station at Ruharo Water Works.

Groundwater potential in the catchment is highly variable, but is generally poor. This is due to natural factors i.e. the hydrogeology and geology of the area. The quality is also poor, especially because of high Iron, Calcium and Magnesium content. Although groundwater levels are monitored at a few specific locations across the catchment, consistent trends could not be identified. Interviews with stakeholders, however, suggested that the yields of operational groundwater sources were gradually reducing.

\subsection{Water quality}

DWRM carries out water quality sampling and monitoring at various locations along the river. However, there was a paucity of consistent data to enable meaningful, long-term assessments of water quality changes over time. Pollution loads in the catchment are expected to continue to grow mainly due to industrial and domestic wastewater discharges, or from surface water runoff from agricultural land and urban areas. A local hospital in Mbarara (Holy Innocents Children's Hospital) is working with the University of San Diego in California, USA to monitor water quality at five river locations upstream and downstream of the hospital [4]. The parameters monitored include $\mathrm{pH}$, conductivity, dissolved 
oxygen concentration and saturation level, phosphate, nitrate, iron, total coliform bacteria, faecal coliform bacteria and enterococci. The university data was not publicly available yet, but the researchers reported never finding any significant difference in each parameter measured between any of the three main sites, or any of the other sporadically measured river sites.

However, it was observed that river bacterial counts tripled after a rain event [4]. This is supported by visual evidence of sediment and erosion of soil into the river. Anecdotal evidence also suggests that waste disposal to the river occurs; during informal interviews with riverside communities, a number stated that during rain storms, there was a "strong smell of sewage" associated with the river. Note that the river is also used for permitted treated wastewater discharge by at least one major industry and the National Water and Sewerage Corporation (NWSC) which provides water and sewerage services to Mbarara town. Discharges from solid waste management facilities (leachate), some hospitals, abattoirs and tanneries are also known to occur although no formal evidence of this was sought.

\subsection{Land use changes and impacts}

The River Rwizi is highly dependent on the ecosystem's ability to restore and maintain the established processes of water and nutrient circulation and energy flows at the basin scale. There is a diverse range of land uses and sensitive ecosystems including wetlands in both the upper and lower reaches, a key wildlife ecosystem (Lake Mburo National Park), grazing lands and crop farm land. Recent changes in land-use patterns mean that parts of the catchment have reduced capacity to absorb variations in rainfall, leading to increased erosion into the river and worsening drought episodes. Loss of tree cover and wetlands means that rainfall is more likely to translate into fast runoff and more frequent flooding. Flooding in the catchment is linked to the efficiency of local drainage in low-lying areas. However, the threat of flooding in the catchment appears to be lower than the threat of drought. Flooding on the River Rwizi is currently perceived as infrequent, occurring about once every ten years, with minimal impact on communities and businesses, whereas drought occurs nearly annually.

\subsection{Water demand projections}

Water demand projections over the 25-year period to 2035 were compiled [5] for the main categories of water use for which information was readily available through national development plans. The main drivers of water demand growth were also identified, and include: increasing human and livestock populations; increasing industrial water demand; increasing irrigation water demand and increased economic activity. The highlights from the water demand assessments can be summarised as follows:

- All the water demand trends examined were increasing, mainly as a result of population growth and increasing urbanisation. Total water demand in the catchment was project to grow from 28 million cubic metres (MCM)/year in 2011 to $93 \mathrm{MCM} /$ year by 2035 (Figure 4). 
- The majority of national level development plans, e.g. for irrigation or domestic water supply, were developed with limited inter-sector coordination, resulting in competing water needs.

- Industrial demands in the catchment currently form the smallest component of water demand, but conversely the most difficult to predict due to the indeterminate manner in which investment opportunities in manufacturing industries may arise. New industrial demands also tend to be supported at a high level politically, which puts pressure on water resources managers.

- Industrial demands that are large in comparison to the available resource at a given location have the potential to significantly affect the availability of the resource at that location, but also further downstream.

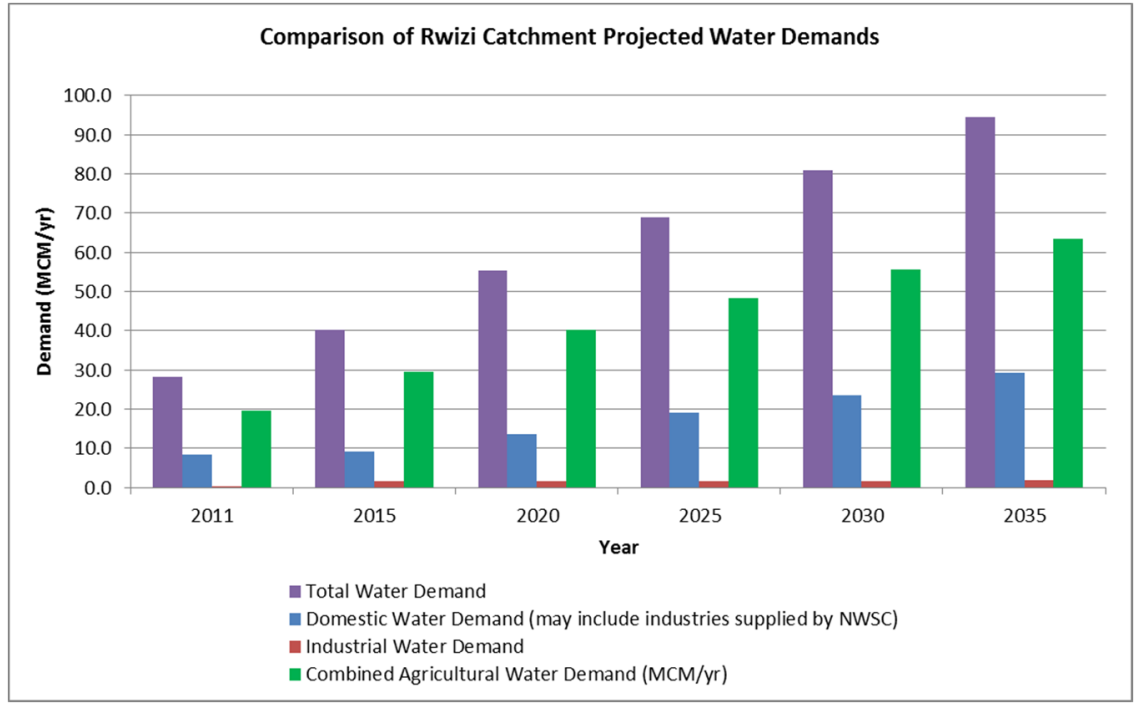

Figure 4: $\quad$ Total water demand projections 2011-2035.

\section{Assessment and mitigation of shared water risk}

The main water-related risks faced by stakeholders in the catchment were identified through the literature review and stakeholder consultation. The risk assessments consider the physical, regulatory and reputational risks that may result from environmental conditions in the catchment, operations, services and regulation.

\subsection{Risk identification}

The shared water risks identified are shown in Table 1, together with their main causes. The causal factors range from local (catchment) factors such as lack of appropriate monitoring data sets and to lack of infrastructure, to wider factors related to the water sector in general. 
Table 1: Water-related risk for Rwizi catchment.

\begin{tabular}{|c|c|}
\hline $\begin{array}{c}\text { Risk to } \\
\text { Stakeholders }\end{array}$ & Main Cause(s) \\
\hline $\begin{array}{l}\text { Risk of inaccurate } \\
\text { water resource } \\
\text { assessments }\end{array}$ & $\begin{array}{l}\text { - Unreliable river flow data set. } \\
\text { - Unreliable monitoring locations. }\end{array}$ \\
\hline $\begin{array}{l}\text { Insufficient water } \\
\text { supply }\end{array}$ & $\begin{array}{l}\text { - Insufficient rainfall from July to September, and from } \\
\text { December to February. } \\
\text { - Lack of adequate, functional water storage infrastructure. } \\
\text { - Limited water supply alternatives (poor yield or utilisation } \\
\text { of existing resources). } \\
\text { - Competing needs. }\end{array}$ \\
\hline Poor quality water & $\begin{array}{l}\text { - Poor natural groundwater quality (hydrogeological factors). } \\
\text { - Catchment activities adversely impacting the surface water } \\
\text { quality. }\end{array}$ \\
\hline $\begin{array}{l}\text { Inconsistent water } \\
\text { service delivery }\end{array}$ & $\begin{array}{l}\text { - Limited coordination within water sector/in water resource } \\
\text { development despite a strong commitment towards delivery } \\
\text { of water services in urban and rural areas. } \\
\text { - Fragmented mandate for service delivery. } \\
\text { - Separate funding streams. } \\
\text { - Lack of capacity and funding at local government level. }\end{array}$ \\
\hline $\begin{array}{l}\text { Competing water } \\
\text { demands }\end{array}$ & $\begin{array}{l}\text { - Significant growth in domestic water need due to } \\
\text { population growth. } \\
\text { - Significant growth in commercial (industrial and } \\
\text { agricultural) water needs. }\end{array}$ \\
\hline $\begin{array}{l}\text { Projected impacts of } \\
\text { climate change }\end{array}$ & $\begin{array}{l}\text { - Increased temperatures are likely to lead to greater water } \\
\text { demand and droughts. }\end{array}$ \\
\hline $\begin{array}{l}\text { Current and future } \\
\text { regulatory risk }\end{array}$ & $\begin{array}{l}\text { - Proposed changes to the current regulatory system that is } \\
\text { being updated. } \\
\text { - Catchment pressures leading to tougher regulatory } \\
\text { standards. }\end{array}$ \\
\hline $\begin{array}{l}\text { Municipal water } \\
\text { shortages }\end{array}$ & $\begin{array}{l}\text { - Inadequate or non-functional infrastructure and } \\
\text { infrastructure breakdowns. } \\
\text { - Insufficient supply, particularly in the dry season. }\end{array}$ \\
\hline Flooding & $\begin{array}{l}\text { - Vegetation loss and draining of wetlands. } \\
\text { - Poor surface water drainage. }\end{array}$ \\
\hline
\end{tabular}




\subsection{Proposed strategic interventions}

Following the identification of the main water-related risks and their causes, strategic interventions to address the risks were explored. The mitigation measures identified in the study were generated through discussion with the catchment stakeholders in the consultative workshops and the one-on-one interviews. For clarity, the actions were categorised into two:

- Interventions relating to the water resources situation in the catchment, and which should be considered further in the development of a management plan.

- Interventions related to improving the institutional framework and which have a wider bearing in the water sector in Uganda (these are described in a separate paper).

The strategic actions are outlined in Table 2.

The strategic mitigation actions would be developed and implemented over the medium to long term. A number of shorter term actions to galvanise action at the catchment level and individual stakeholder level were proposed, together with an indication of likely budgets. The catchment-based water resources management approach currently being implemented in the Rwizi catchment, and the stakeholder involvement through the $\mathrm{CMO}$ are considered the most suitable approach to implement the mitigation actions. This includes current initiatives on water stewardship and the nascent partnership with private industry, under which the risk assessment was carried out.

\section{Conclusions}

This study identified and ranked key risks affecting the water users in the catchment, including the causal factors. The key shared risks identified can be categorised as follows:

- Water supply risk due to poor decision-making (unreliable data), insufficient seasonal river flows in the dry season, poor surface and groundwater quality and limited alternatives for water supply.

- Water supply, environmental and regulatory risk due to fragmented delivery of water services and a lack of coordination in resource development.

- Environmental risk due to insufficient environmental assessment of projects in the catchment.

- Regulatory risk due to lack of institutional capacity.

- Overall business risk arising from water supply, environmental and regulatory risks.

Possible mitigation measures were identified and strategic actions identified for consideration in the development of the Catchment Management Plan. 
Table 2: Proposed strategic mitigation interventions.

\begin{tabular}{|c|c|}
\hline $\begin{array}{l}\text { Proposed intervention } \\
\text { to reduce water risk }\end{array}$ & Comment \\
\hline $\begin{array}{l}\text { Construction of a large } \\
\text { surface water storage } \\
\text { reservoir at a suitable } \\
\text { location in the catchment. }\end{array}$ & $\begin{array}{l}\text { The catchment stakeholders agreed that surface water } \\
\text { storage is critical for the catchment. This may take the form } \\
\text { of one or more surface water reservoirs of 'significant' } \\
\text { volume at a suitable locations or locations to provide water } \\
\text { supply storage and possibly flood attenuation. }\end{array}$ \\
\hline $\begin{array}{l}\text { Exploring sub-surface } \\
\text { water storage through } \\
\text { techniques such as } \\
\text { Managed Aquifer } \\
\text { Recharge (MAR)/Aquifer } \\
\text { Storage and Recharge } \\
\text { (ASR). }\end{array}$ & $\begin{array}{l}\text { MAR and ASR techniques involve the intentional recharge } \\
\text { of water to groundwater aquifers either for subsequent } \\
\text { recovery and use for water supply or for environmental } \\
\text { benefit. Groundwater may be recharged by diverting water } \\
\text { into existing shallow wells, or infiltrating water through the } \\
\text { floor of constructed water galleries and soakaways. } \\
\text { Geological characteristics may limit the usefulness of such } \\
\text { techniques in this catchment. }\end{array}$ \\
\hline $\begin{array}{l}\text { Develop environmental } \\
\text { management and land } \\
\text { restoration programmes, } \\
\text { such as wetland and } \\
\text { forest restoration } \\
\text { schemes. }\end{array}$ & $\begin{array}{l}\text { Stakeholders in the catchment called for a wide range of } \\
\text { environmental activities to be implemented, including } \\
\text { restoration of wetlands that have been drained (for } \\
\text { agriculture, construction or gold mining). Reforestation or } \\
\text { replanting of de-vegetated areas would also be proposed, } \\
\text { with particular attention being paid to critical or sensitive } \\
\text { areas of the watershed such as river banks. For such } \\
\text { programmes to be successful, they would need to be } \\
\text { implemented consistently across the catchment. The cost- } \\
\text { benefit assessment also highlighted the need for them to } \\
\text { demonstrably compete favourably against present land use } \\
\text { patterns and livelihoods. }\end{array}$ \\
\hline $\begin{array}{l}\text { Agricultural land } \\
\text { management } \\
\text { programmes. }\end{array}$ & $\begin{array}{l}\text { Stakeholders in the catchment stated the need for } \\
\text { programmes to help farmers understand the impacts of their } \\
\text { current agricultural practices, and to implement practices } \\
\text { that improve the sustainability of the catchments water } \\
\text { resources. They called for such programmes to be science- } \\
\text { based and backed by policy in order to maximise the impact } \\
\text { and avoid abortive interventions. Like the environmental } \\
\text { programmes, the agricultural programmes would need to be } \\
\text { implemented consistently across the whole catchment. }\end{array}$ \\
\hline $\begin{array}{l}\text { Develop solid waste and } \\
\text { storm water runoff } \\
\text { management plans in } \\
\text { urban and semi-urban } \\
\text { areas. }\end{array}$ & $\begin{array}{l}\text { Municipalities and town councils in the catchment are key } \\
\text { contributors to waterway pollution due to a lack of solid } \\
\text { waste collection, urban runoff and poor regulation of waste } \\
\text { disposal. Development of waste management plans should } \\
\text { be done for all major urban centres in the catchment and } \\
\text { regulation enforced. Poor solid waste management and } \\
\text { disposal in Mbarara town, in particular, was highlighted in } \\
\text { the stakeholder interviews as a key contributor to pollution } \\
\text { of the river. }\end{array}$ \\
\hline
\end{tabular}




\section{References}

[1] Atim, J., Application of Integrated Water Resources Management in Computer Simulation of River Basin's Status - Case Study of River Rwizi, Master's Thesis, Faculty of Engineering and Technology, Vaal University of Technology, South Africa, pp. 34-43, 2010.

[2] UNESCO-WWAP, Water - A Shared Responsibility, The United Nations World Water Development Report 2, p. 143, 2006.

[3] Ntale, H.K., River Ruizi Water Balance Analysis, Vala Associates Ltd., p. 48, 2012.

[4] Bolender, J.P., Personal Communication, 27 November 2013, Associate Professor, Chemistry and Biochemistry, University of San Diego, California, USA.

[5] Newplan Ltd., Assessment and Mapping of Water Use and Demand in Lake Victoria Basin - Lot 1 \& 2: Ref No: Mwe/Srvcs/08-09/00489, pp. 21-96, 2013. 